\title{
Perinatal mortality among twins and singletons in a city in southeastern Brazil, 1984-1996
}

\author{
Bernardo Beiguelman ${ }^{1}$ and Carla Franchi-Pinto ${ }^{2}$
}

\begin{abstract}
Analysis of 116,699 deliveries (1062 twin pairs and 115,637 singletons) which occurred from 1984 to 1996 at the largest obstetric center in Campinas, SP, Brazil, provided the following conclusions: 1$)$ despite the low percentage of twin births $(0.9 \%)$, $10.7 \%$ of all early neonatal deaths and $3.5 \%$ of all stillbirths were twins. Compared to singletons, the likelihood of stillbirths and early neonatal deaths among twins was 1.9 and 6.5 times greater, respectively. 2) The proportion of twins among early neonatal deaths tended to decrease, probably because of improvements in prenatal and perinatal care. 3) The critical period for early neonatal deaths in singletons and twins lasted for the three first days after birth. 4) The incidence of perinatal deaths among twins was highest among MM pairs, followed by FF pairs, and lowest among MF pairs. 5) There was a trend towards a decrease in the annual rate of early neonatal deaths among both singletons and twins, and of stillbirths among singletons, the latter being more conspicuous among females. 6) The sex ratio of singletons was practically stable among living newborns, but showed strong cyclic variation among early neonatal deaths, and a tendency to increase among stillbirths. Twins who died in the first week, as well as living twins showed a strong increase in their sex ratio from 1984 to 1996. 7) The mean gestational age of singletons was highest among living newborns followed by stillbirths, and was lowest among early neonatal deaths. The mean gestational age of living twins was higher than that of early neonatal deaths, but not different from that of stillbirths. 8) The mean birth weight of singletons and twins was highest among living newborns, followed by stillbirths, and lowest among early neonatal deaths. 9) Apgar scores $\geq 7$ obtained five minutes after birth are inadequate as a reliable indicator of the clinical condition of the newborn, since almost half of the early neonatal deaths had 5-min Apgar scores varying from 7 to 10.
\end{abstract}

\section{INTRODUCTION}

Perinatal deaths include stillbirths plus early neonatal deaths, defined as the deaths occurring in the first week after birth (Belitzky et al., 1978). A knowledge of perinatal mortality rates is very useful for evaluating indirectly the results of prenatal and perinatal care since any improvement results in a striking decrease in the early neonatal death and stillbirth rates (Osbourne and Patel, 1985; Papiernik et al., 1985). The perinatal mortality rate of twins is higher than that of singletons in all populations studied (Chen et al., 1992). Since there is little information on this aspect for Brazilian twins, we have investigated the frequency of stillbirths and of early neonatal deaths among twins and singletons born in a large city in southeastern Brazil.

\section{SUBJECTS AND METHODS}

One thousand and sixty-two twin pairs (412 MM, 279 MF and 371 FF pairs) and 115,637 singletons born from 1984 to 1996 were investigated using the records of the largest obstetric center (Maternidade de Campinas) in the city of Campinas, SP, Brazil, which assists women belonging to all social segments of the population ( $40 \%$ private patients, $59 \%$ welfare program patients and $1 \%$ indigents).

Fetuses weighing $\leq 500 \mathrm{~g}$ were excluded from the study and classified as abortions, since this fetal weight corresponds to a gestational age of 20-22 weeks (Belitzky et al., 1978). Children born without both respiratory and voluntary muscle movements, and no heartbeat or umbilical cord pulse were considered as stillbirths, while children who died in the first seven days of life were classified as early neonatal deaths. Data on early neonatal deaths were obtained for the entire period, while data on stillbirths were restricted to the period from 1988 to 1996. As the twins were not classified by any available zygosity test, the frequency of monozygotic pairs was estimated using the classic Weinberg differential rule (1901).

The twins who remained alive and a sample of 1522 singletons born in the same period and in the same hospital as the twins were used as controls for comparison of the gestational age, birth weight, and Apgar scores of stillbirths and neonates who died in the first week after birth. Since the records of these 1522 singletons were not always complete, the number of control cases varied slightly for gestational age, birth weight and Apgar scores.

Newborns with gestational ages less than 37 weeks were classified as preterm. Gestational ages of 37-42 weeks indicated newborns at term, while gestational ages of more than 42 weeks indicated post-mature newborns (Belitzky et al., 1978). Children born with less than 2,500 $\mathrm{g}$ were classified as low birth weight, and those with less than $1,500 \mathrm{~g}$ at birth as very low birth weight (Keith, 1994). The clinical condition of the newborns was evaluated using

${ }^{1}$ Laboratório de Epidemiologia Genética, Departamento de Parasitologia, ICB, USP, São Paulo, SP, Brasil. ${ }^{2}$ Serviço de Genética Médica do Hospital da Sta. Casa de Misericórdia, São Paulo, SP, Brasil. Send correspondence to B.B. Rua Angelina Maffei Vita, 408, Apto. 41, 01455-070 São Paulo, SP, Brasil. E-mail: bernardo@deane.icb.usp.br 
Apgar scores (Apgar, 1953) obtained 1 min and 5 min after birth. Apgar scores were divided into two classes: $<7$ (bad prognosis) and $\geq 7$ (good prognosis), since scores varying from 7 to 10 indicated a very low risk of respiratory or neuropsychomotor developmental complications, while scores from 4 to 6 indicated moderate asphyxia, and scores lower than 4 were associated with a high risk of mortality and cerebral palsy (Grothe and Rüttgers, 1985; Committee on Fetus and Newborn, AAP, 1986; Fanaroff and Martin, 1992).

The best fit curves for the distribution of the data were obtained using the software Curve Fits (version 4.27).
The proportions were compared using the chi-square or Fisher's exact test, while the variances and the means were compared using the F- and Student's $t$-test, respectively.

\section{RESULTS AND DISCUSSION}

The data on single and twin births covering the period from 1984 to 1996 are shown in Tables I and II, respectively. These data include the number of newborns per year classified according to sex, early neonatal death and stillbirth rates, as well as their sex ratio. Based on these data, the proportion of twins among the newborns was only

Table I - Early neonatal death rate per 1,000 (NDR) from 1984 to 1996 and stillbirth rate per 1,000 (STR) from 1988 to 1996 among singletons born at the Maternidade de Campinas. The sex ratios (number of males per 100 females) of all singletons, of those who died in the first week (ND) and of stillborn (ST) singletons are also shown.

\begin{tabular}{|c|c|c|c|c|c|c|c|c|c|c|c|c|}
\hline \multirow[t]{2}{*}{ Year } & \multicolumn{3}{|c|}{ Males } & \multicolumn{3}{|c|}{ Females } & \multicolumn{3}{|c|}{ Total* } & \multicolumn{3}{|c|}{ Sex ratio } \\
\hline & No. & NDR & STR & No. & NDR & STR & No. & NDR & STR & Births & ND & ST \\
\hline 1984 & 4498 & 8.23 & & 4261 & 11.03 & & 8786 & 9.56 & & 106.6 & 78.7 & \\
\hline 1985 & 4626 & 9.73 & & 4559 & 8.55 & & 9197 & 9.13 & & 101.5 & 115.4 & \\
\hline 1986 & 4693 & 11.51 & & 4579 & 12.23 & & 9284 & 12.06 & & 102.5 & 96.4 & \\
\hline 1987 & 3868 & 8.53 & & 3776 & 6.36 & & 7653 & 7.45 & & 102.4 & 137.5 & \\
\hline 1988 & 4560 & 10.96 & 11.84 & 4300 & 5.58 & 8.14 & 8871 & 8.45 & 10.26 & 106.0 & 208.3 & 154.3 \\
\hline 1989 & 4432 & 9.93 & 11.73 & 4304 & 8.36 & 12.08 & 8748 & 9.26 & 12.96 & 103.0 & 122.2 & 100.0 \\
\hline 1990 & 4287 & 9.80 & 10.73 & 3876 & 11.61 & 9.55 & 8176 & 10.64 & 10.40 & 110.6 & 93.3 & 124.3 \\
\hline 1991 & 4091 & 7.82 & 8.56 & 3841 & 8.59 & 10.41 & 7951 & 8.30 & 10.19 & 106.5 & 97.0 & 87.5 \\
\hline 1992 & 4230 & 11.11 & 11.82 & 4186 & 9.32 & 7.88 & 8419 & 10.21 & 9.86 & 101.1 & 120.5 & 151.5 \\
\hline 1993 & 4614 & 7.37 & 9.32 & 4328 & 6.47 & 7.62 & 8943 & 7.04 & 8.50 & 106.6 & 121.4 & 130.3 \\
\hline 1994 & 4853 & 4.74 & 7.62 & 4756 & 5.05 & 7.36 & 9611 & 4.99 & 8.32 & 102.0 & 95.8 & 105.7 \\
\hline 1995 & 5073 & 9.07 & 11.43 & 4837 & 5.58 & 9.30 & 9915 & 7.36 & 10.39 & 104.9 & 170.4 & 128.9 \\
\hline 1996 & 5096 & 8.05 & 10.40 & 4983 & 3.61 & 8.23 & 10083 & 5.85 & 9.32 & 102.3 & 227.8 & 129.3 \\
\hline Total & 58921 & 8.96 & 10.39 & 56586 & 7.78 & 8.91 & 115637 & 8.43 & 9.99 & 104.1 & 120.0 & 121.9 \\
\hline
\end{tabular}

*The total numbers do not correspond exactly to the sum of the males and females since they include newborns of unknown sex.

Table II - Early neonatal death rate per 1,000 (NDR) from 1984 to 1996, number of stillbirths (ST) and stillbirth rate per 1,000 (STR) from 1988 to 1996 among twins born at the Maternidade de Campinas.

The sex ratios (number of males per 100 females) of all newborn co-twins and of those who died in the first week (ND) are also shown.

\begin{tabular}{|c|c|c|c|c|c|c|c|c|c|c|c|}
\hline \multirow[t]{2}{*}{ Year } & \multicolumn{3}{|c|}{ Males } & \multicolumn{3}{|c|}{ Females } & \multicolumn{3}{|c|}{ Total } & \multicolumn{2}{|c|}{ Sex ratio } \\
\hline & No. & NDR & ST & No. & NDR & ST & No. & NDR & STR & TWINS & NDR \\
\hline 1984 & 52 & 115.38 & & 100 & 40.00 & & 152 & 65.79 & & 52.0 & 150.0 \\
\hline 1985 & 83 & 132.53 & & 73 & 95.89 & & 156 & 115.38 & & 113.7 & 157.0 \\
\hline 1986 & 88 & 79.54 & & 84 & 71.43 & & 172 & 75.58 & & 104.8 & 116.7 \\
\hline 1987 & 65 & 30.76 & & 63 & 111.11 & & 128 & 70.31 & & 103.2 & 28.6 \\
\hline 1988 & 81 & 37.04 & 2 & 85 & 94.12 & - & 166 & 66.26 & 12.05 & 95.3 & 37.5 \\
\hline 1989 & 79 & 50.63 & 1 & 61 & 32.79 & 2 & 140 & 42.86 & 21.43 & 129.5 & 200.0 \\
\hline 1990 & 65 & 76.92 & 4 & 69 & 28.99 & 2 & 134 & 52.24 & 44.78 & 94.2 & 250.0 \\
\hline 1991 & 89 & 67.42 & 1 & 79 & 50.63 & - & 168 & 59.52 & 5.95 & 112.7 & 150.0 \\
\hline 1992 & 88 & 79.54 & - & 80 & 12.50 & - & 168 & 47.62 & - & 110.0 & 700.0 \\
\hline 1993 & 69 & 28.99 & - & 73 & 13.70 & 1 & 142 & 21.13 & 7.04 & 94.5 & 200.0 \\
\hline 1994 & 100 & 40.00 & 8 & 80 & 37.50 & - & 180 & 38.89 & 44.44 & 125.0 & 133.3 \\
\hline 1995 & 127 & 39.37 & 3 & 109 & 9.17 & 3 & 236 & 25.42 & 25.42 & 116.5 & 500.0 \\
\hline 1996 & 117 & 76.92 & - & 65 & - & 2 & 182 & 49.45 & 10.99 & 180.0 & - \\
\hline Total & 1103 & 64.37 & 19 & 1021 & 45.05 & 10 & 2124 & 55.08 & 19.13 & 108.0 & 154.3 \\
\hline
\end{tabular}


$1.8 \%$, indicating that the percentage of twin deliveries was less than one percent $(0.9 \%)$. In spite of the low percentage of twin births in this period, $10.7 \%$ of all early neonatal deaths and $3.5 \%$ of all stillbirths were twin births. Twins were thus responsible for $7.6 \%$ of all perinatal deaths. Compared to singletons, the likelihood of stillbirths, early neonatal death and perinatal mortality among twins was $1.9,6.5$, and 4 , respectively. These figures are consistent with data reported elsewhere (Osbourne and Patel, 1985; Papiernik et al., 1985; Doherty, 1988; Lumme and Saarikoski, 1988; Spellacy et al., 1990; Kiely, 1991; Fraser et al., 1991; Chen et al., 1992; Keith, 1994). The early neonatal death rate/stillbirth rate ratio among twins (2.9) was almost 2.5 times higher than that among singletons (1.2)

The high proportion of twins among early neonatal deaths was an average value, and there was a tendency for this frequency to decrease as shown clearly in the best fit regression curve for the annual variation of this proportion (Figure 1). This decline probably reflects the improvement in the conditions of obstetric and pediatric practice. The use of ultrasound, which enabled the early diagnosis of multiple gestation and increased the frequency of women who received prenatal care, and the improvement in perinatal care were factors that undoubtedly contributed to the increase of the survival of twin births.

Because of the higher perinatal death rate of twins compared with singletons, it was reasonable, when considering early neonatal or stillbirth death rates, to separate them according to whether they were singletons or twins. Indeed, if the data in Tables I and II had been pooled, the high neonatal death rate observed among twins (55.08 per thousand) would not have been detected since, in the total sample of newborns, the rate would have been estimated as 9.27 per thousand. Similarly, the stillbirth rate would have been estimated as 10.15 per thousand in the total sample, thereby obscuring the high stillbirth rate among twins (19.93 per thousand).

Table III shows that the distribution of early neonatal deaths among singletons and twins according to the days elapsed from birth did not differ significantly, allowing an estimate that almost $80 \%$ of all neonatal deaths occurred in the first three days after birth. Thus, in contrast to other populations (Barr and Stevenson, 1961; Doherty, 1988), the critical period for the early neonatal deaths of both singletons and twins was not limited to the first day after birth.

Perinatal mortality was not uniform among MM, FF and MF twin pairs, a phenomenon already pointed out elsewhere (Lowe and Record, 1951; Barr and Stevenson, 1961; Myrianthopoulos, 1970; Rydhström, 1990). Table IV shows that the incidence of stillbirths and early neonatal deaths was highest among MM pairs, followed by FF twins and lowest among MF pairs. Thus, when the stillbirths and early neonatal deaths were pooled, irrespective of whether one or both elements of the pairs were affected, the pro-

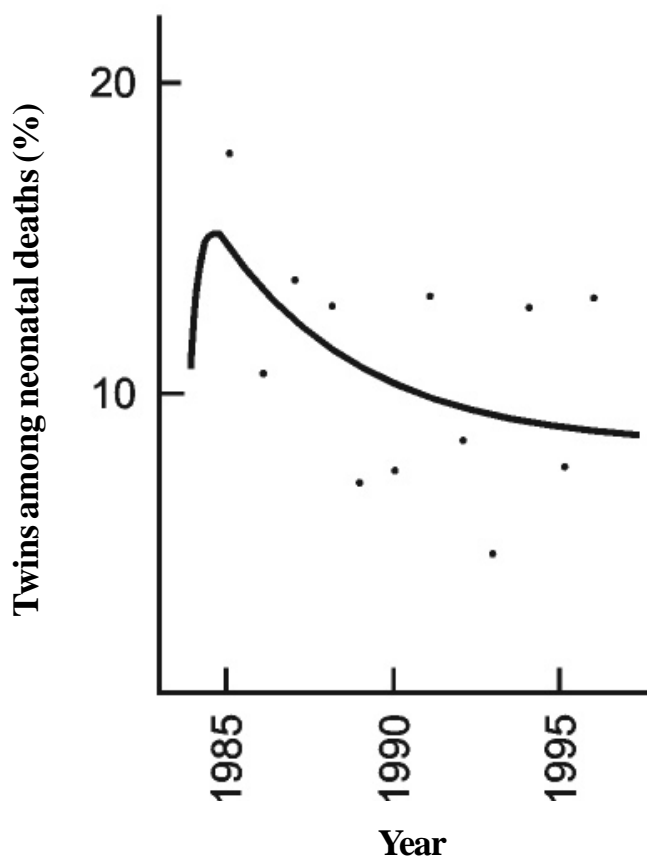

Figure 1 - Best fit regression curve for the annual distribution (1984-1996) of the percentage of twins among neonatal deaths $(y=6.689+28.145-23.851)$

year year ${ }^{2}$

Table III - Distribution (\%) of early neonatal deaths among singletons and twins according to the days elapsed from birth.

\begin{tabular}{|lccc|}
\hline Day & Singletons $(\mathrm{N}=977)$ & Twins $(\mathrm{N}=117)$ & Total $(\mathrm{N}=1094)$ \\
\hline 1st & 36.7 & 29.1 & 35.9 \\
2nd & 25.2 & 32.5 & 26.0 \\
3rd & 16.0 & 15.4 & 15.9 \\
4th & 8.5 & 10.2 & 8.7 \\
5th & 6.6 & 6.0 & 6.6 \\
6th & 4.9 & 3.4 & 4.7 \\
7th & 2.1 & 3.4 & 2.2 \\
\hline
\end{tabular}

$\chi^{2}=5.61 ; 6$ d.f.; $0.30<\mathrm{P}<0.50$.

Table IV - Stillbirths and early neonatal deaths among MM, FF and MF twin births, and estimates of the proportion of monozygotic pairs (MZ) among like-sex pairs

\begin{tabular}{|c|c|c|c|c|c|c|c|c|}
\hline \multicolumn{2}{|c|}{ Pairs } & \multicolumn{3}{|c|}{ Stillbirths } & \multicolumn{3}{|c|}{ Early neonatal deaths } & \multirow[t]{2}{*}{$\mathrm{MZ}$} \\
\hline Type & No. & One & Both & Total & One & Both & Total & \\
\hline MM & 412 & 8 & 5 & $13(3.2 \%)$ & 13 & 23 & $36(8.7 \%)$ & $66.0 \%$ \\
\hline $\mathrm{FF}$ & 371 & 2 & 3 & $5(1.4 \%)$ & 10 & 12 & $22(5.9 \%)$ & $62.5 \%$ \\
\hline MF & 279 & $3 *$ & 0 & $3(1.1 \%)$ & $4 * *$ & 10 & $14(5.0 \%)$ & - \\
\hline
\end{tabular}

$* 1 \mathrm{M}+2 \mathrm{~F}, * * 2 \mathrm{M}+2 \mathrm{~F}$ 
portions of perinatal deaths among MM (11.9\%), FF $(7.3 \%)$ and $\mathrm{MF}(6.6 \%)$ twin pairs were significantly different $\left(\chi^{2}=8.532 ; 2\right.$ d.f.; $\left.\mathrm{P}<0.02\right)$.

It is not easy to explain these differences. If the wellknown higher vulnerability of male births were the only cause for the excessive perinatal losses among MM twins, one would expect the proportion of perinatal deaths to be higher among MF pairs than among FF pairs. On the other hand, if monozygotic pairs, which were highly frequent in the present series of twins ( $66 \%$ for MM and $62.5 \%$ for FF pairs), were the only factor responsible for the excessive perinatal deaths among like-sex twins (Barr and Stevenson, 1961; Myrianthopoulos, 1970; Rydhström, 1990), then one would expect MM and FF pairs to show similar frequencies of losses. Since this is not true, and taking into account that the data in Table IV show a significant excess of perinatal deaths affecting both elements of the twin pairs, the gradient MM > FF > MF may be explained by assuming an association of higher vulnerability of male births with monozygosity and an excess of concordant pairs concerning perinatal deaths. This would explain also why the sex ratio of perinatal deaths in twins was higher than that observed among singletons (Tables I and II).

The regression curves that best fitted for the distribution of the annual early neonatal death rates for males, females and both sexes together among singletons and twins are shown in Figures 2 and 3. Figure 2 shows a decrease in the annual rate of early neonatal deaths among singletons, which was more conspicuous among females. The same tendency of this death rate to decrease was seen when male and female twins were pooled (Figure 3), although the annual variation in the early neonatal death rate of twins was not as homogeneous as that of singletons. Indeed, the best fit regression curve for this variation was sinusoidal for males and inverse for females. In any case, the tendency of the annual early neonatal death rate to decrease was more conspicuous among female newborns (singletons or twins) than among males.

Figure 4 shows the best fit regression curves for the annual distribution of the stillbirth rates for singletons and twins. Again, the tendency of the stillbirth rate of singletons to decrease, represented by an inverse regression curve, was influenced by the female newborns. Thus, the quadratic regression curve that best fit the stillbirths rate for male singletons indicated an increase, instead of a decrease in tendency. The sinusoidal regression curve representing the annual variation of the stillbirth rate among twins showed a cyclic variation of this trait around the mean value, although it should be stressed that these rates were based on a small number of stillbirths (Table II).

The sexual differences observed in Figures 2 and 3 are reflected in Tables I and II by the higher proportion of male as compared to female neonatal deaths $\left(\chi^{2}=4.881\right.$; 1 d.f.; $\mathrm{P}<0.05)$ and stillbirths $\left(\chi^{2}=6.608 ; 1\right.$ d.f.; $\left.\mathrm{P}<0.05\right)$ in the total sample of singletons. The same comparisons in twins produced no significant differences $\left(\chi^{2}=3.801\right.$; 1 d.f.; $0.05<\mathrm{P}<0.10 ; \chi^{2}=1.644 ; 1$ d.f.; $\left.0.10<\mathrm{P}<0.20\right)$, perhaps because of the smaller sample size.

Table I shows that from 1984 to 1996 the annual variation of the sex ratio of singletons was very small, the standard deviation calculated for the annual ratios (2.85) being less than 3\% (2.73\%) of the mean (104.3). This stability around a mean value was confirmed by the very small amplitude of the best fit sinusoidal regression curve shown in Figure 5. In contrast, the best fit sinusoidal regression curve for the annual distribution of the sex ratio of singletons who died in the first week after birth was compatible with a cyclic variation of this ratio. The standard deviation calculated for this distribution (45.81) was $35.3 \%$ of the mean sex ratio (129.6), indicating a rather large average
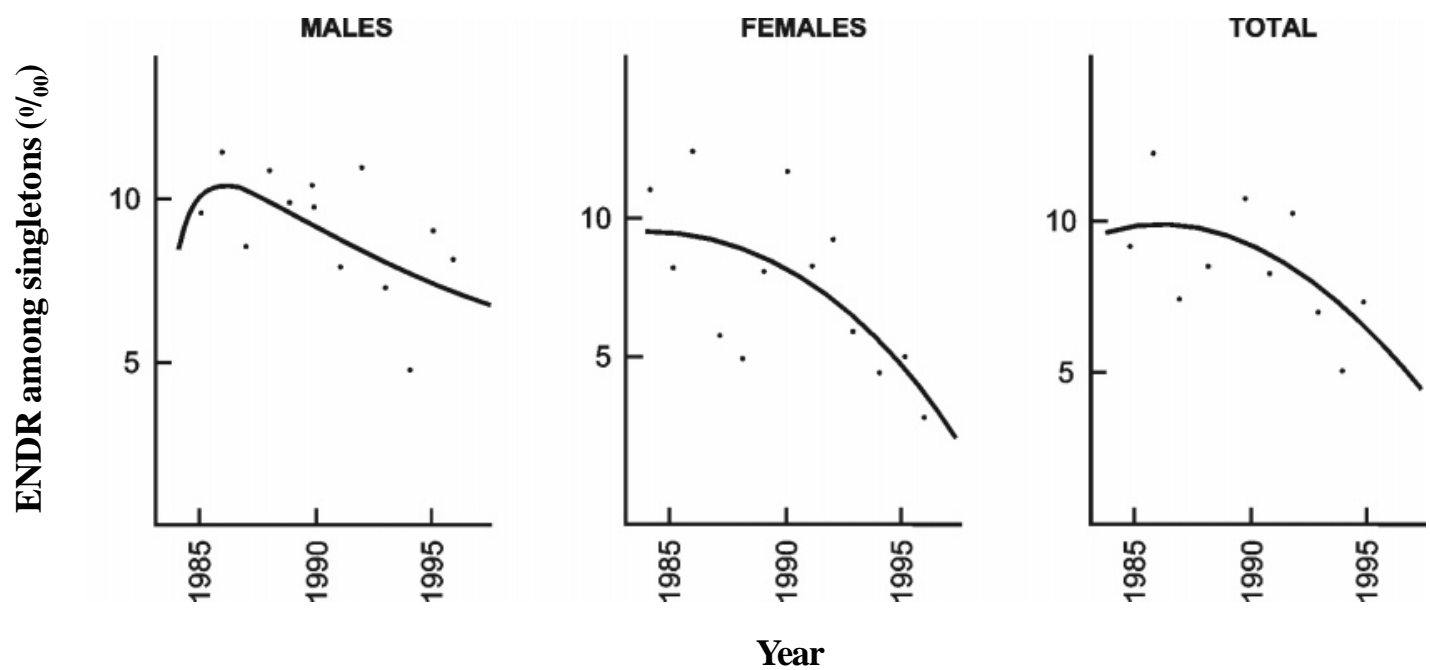

Figure 2 - Best fit regression curves for the annual distribution of the early neonatal death rate (ENDR) among singletons born from 1984 to

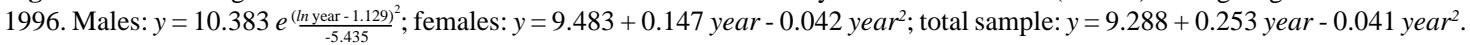



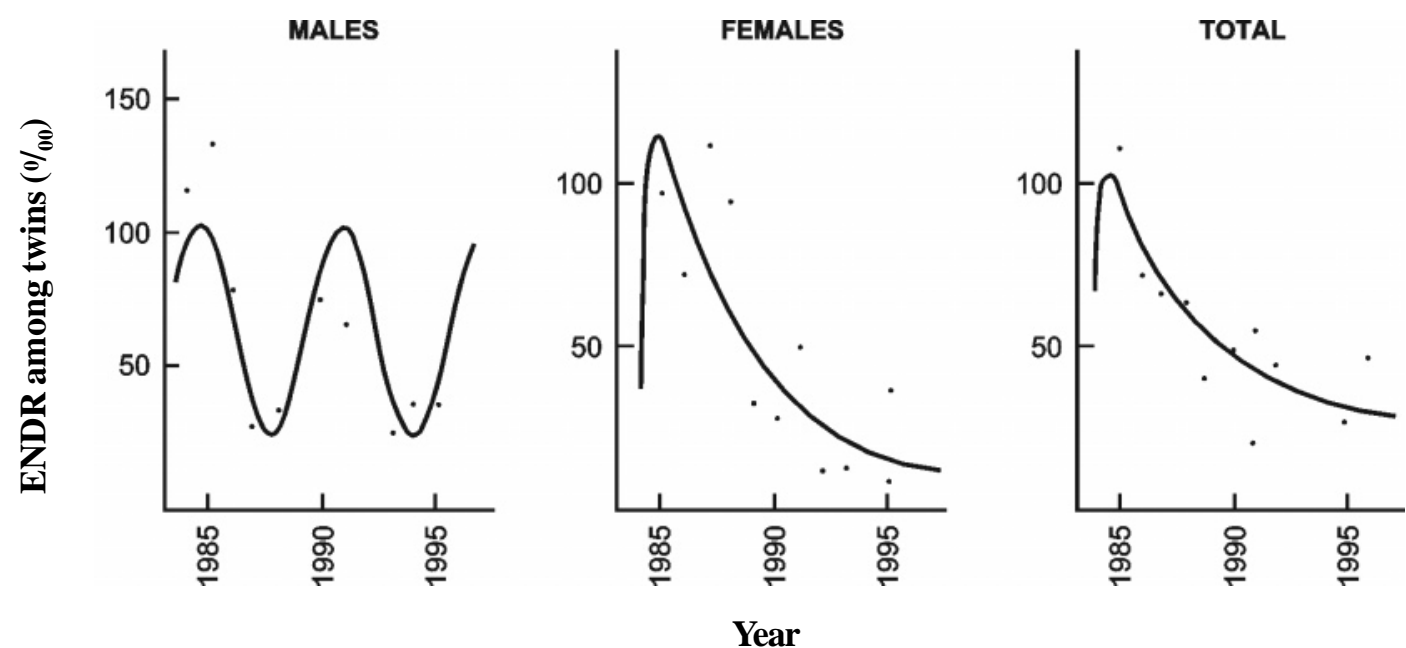

Figure 3 - Best fit regression curves for the annual distribution of the early neonatal death rate (ENDR) among twins born from 1984 to 1996. Males: $y=64.958+37.534 \sin ($ year -0.038$)$; females: $y=17.835+\underline{463.984}-\underline{409.236})$; total sample $(y=11.185+\underline{311.950}-\underline{255.785})$
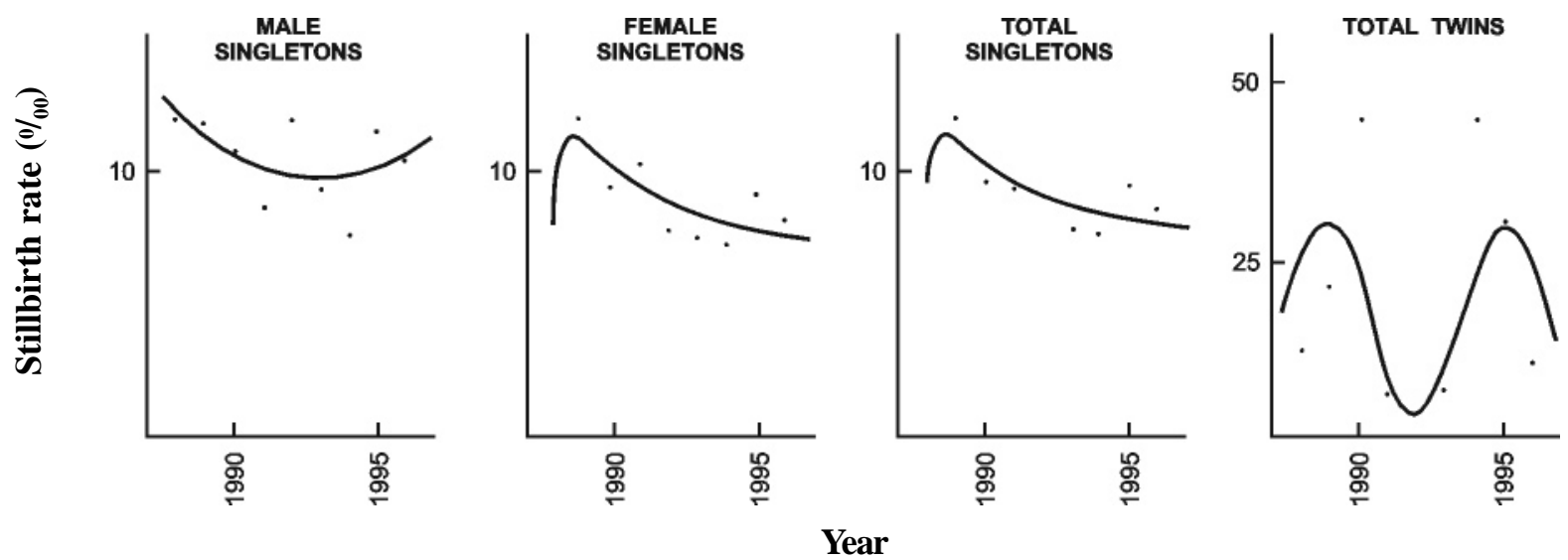

Figure 4 - Best fit regression curves for the annual distribution (1988-1996) of the stillbirth rate of males $\left(y=13.331-1.259\right.$ year +0.106 year $\left.{ }^{2}\right)$, females $\left(y=5.643+\frac{19.991}{\text { year }}-\frac{17.389}{\text { year }^{2}}\right)$ and total sample of singletons $\left(y=7.134+\frac{16.254}{\text { year }}-\frac{13.008}{\text { year }^{2}}\right)$, as well as of twins $[y=16.709+13.213 \sin (y e a r-0.239)]$.

amplitude for this annual distribution (Table I; Figure 5). The last curve in Figure 5, which represents the best fit inverse regression curve for the annual distribution of the sex ratio of stillbirth singletons (Table I), shows a tendency towards an increase in their sex ratio. Finally, the best fit quadratic regression curves for the annual variation of the sex ratio of twin births and of twins who died in the first week after birth (Figure 6; Table II), indicate a strong tendency of the sex ratio to increase from 1984 to 1996.

The mean gestational age of twin births is three weeks less than that of singletons (Beiguelman et al., 1997). Since the birth weight is highly dependent on the length of gestation (Pilotto et al., 1993), at birth, twins weigh significantly less than singletons (Beiguelman et al., 1997).
In contrast to the numerous reports on the gestational age and birth weight of singletons and twins (McKeown and Record, 1952; Powers, 1973; Gedda et al., 1981; Leroy et al., 1982; Watson and Campbell, 1986; Bonnelykke et al., 1987; Alfieri et al., 1987; Buckler and Buckler, 1987; Bleker et al., 1988; Keith 1994; Luke, 1996; Beiguelman et al., 1997), little is known of these traits in stillbirths and early neonatal deaths.

The shorter mean length of gestation and the lower birth weight of twins suggests that these traits should be studied separately in stillbirths and neonatal deaths of twins and singletons (Tables V and VI). Table V shows that stillbirths have a significantly higher mean gestational age than early neonatal deaths among both singletons $(t=4.250$; 

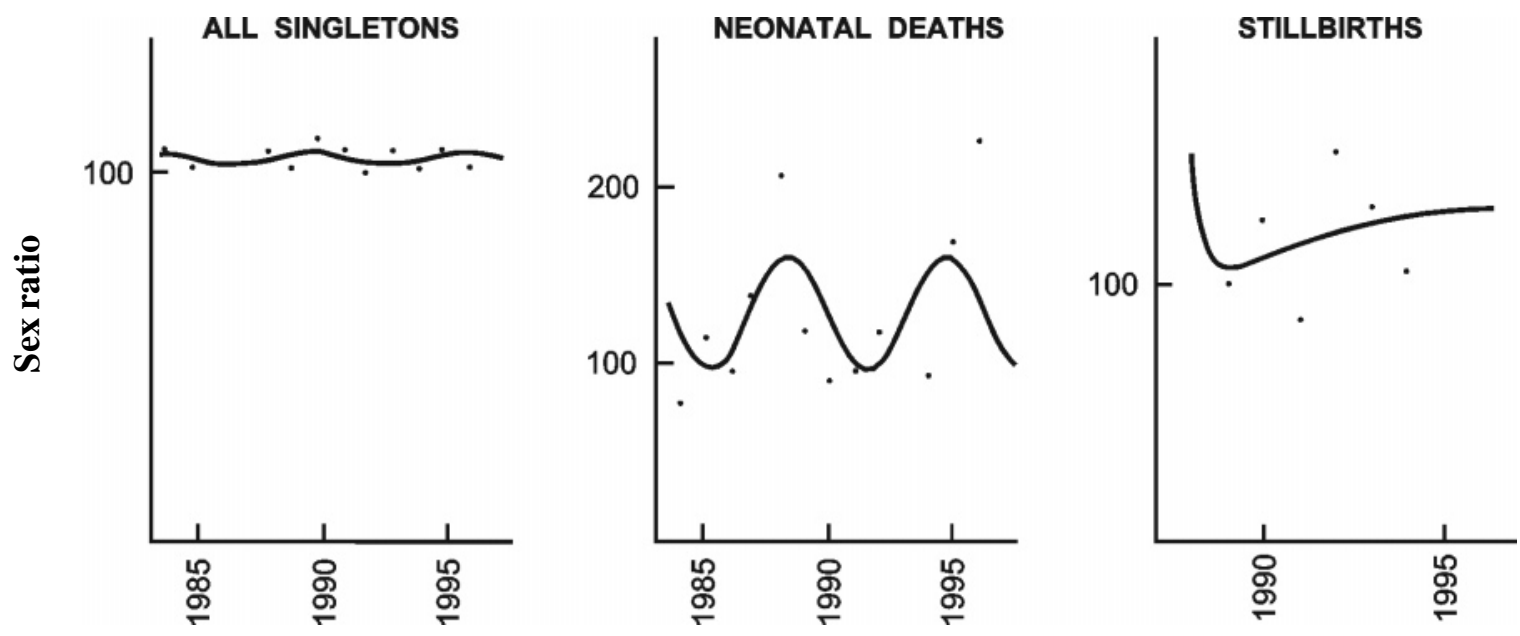

Year

Figure 5 - Best fit regression curves for the annual sex ratio distribution of all newborn singletons $[y=104.260+1.450 \sin (y e a r+1.145)]$, of those who died in the first week $[y=129.450-31.596 \sin ($ year -0.765$)]$ and of stillborn singletons $(y=145.886-\underline{165.247}+\underline{172.948})$. The curves for all singletons and for those who died in the first week refer to the period from 1984 to 1996, while the curve for stillbirths refers to the period from 1988 to 1996.
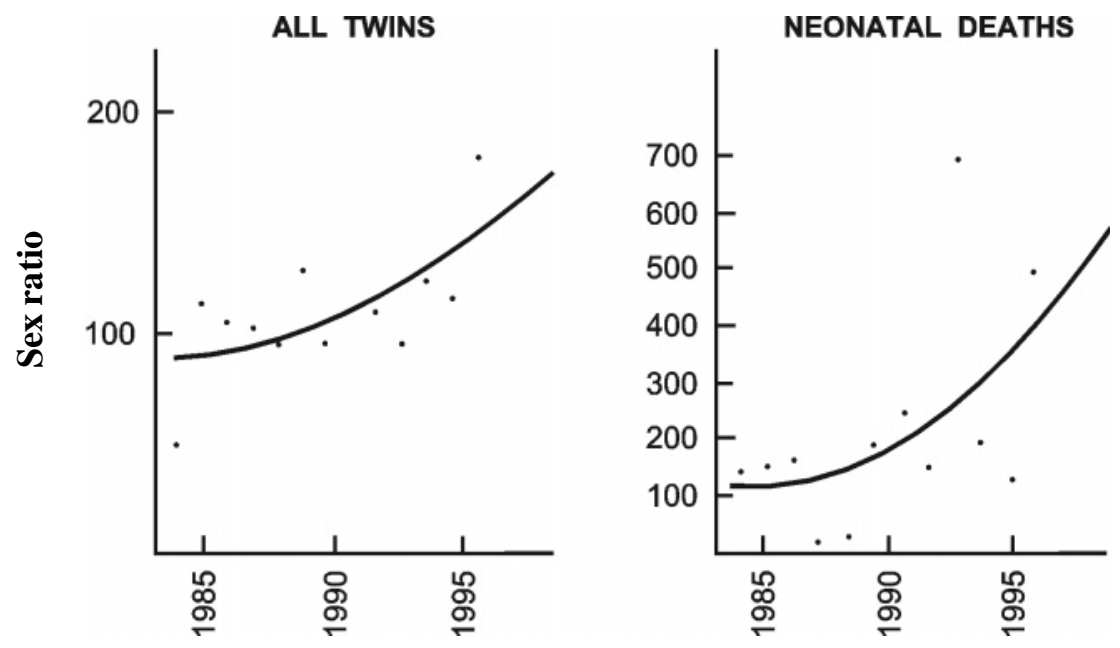

Year

Figure 6 - Best fit regression curves for the annual sex ratio distribution (1984-1996) of all newborn twins $(y=87.686+0.572$ year + 0.292 year $\left.^{2}\right)$ and of those who died in the first week $\left(y=124.0-5.208\right.$ year +2.448 year $\left.^{2}\right)$.

d.f. $=\infty ; \mathrm{P}<0.001)$ and twins $(\mathrm{t}=3.829 ; 64$ d.f.; $\mathrm{P}<0.001)$ This table also shows that the smaller mean gestational age of early neonatal deaths compared with that of stillbirths was caused by a very high proportion of preterm deliveries (less than 37 weeks) among the former (67.8\% of singletons and $82.3 \%$ of twins who died in the first week after birth).

The mean gestational age of singletons who remained alive for at least seven days after birth was significantly greater $(39.5 \pm 2.4$ weeks $)$ than for singleton stillbirths (34.4 \pm 5.6 weeks) and early neonatal deaths (33.0 \pm 5.7 weeks). This clearly reflected the fact that most of the newborns who remained alive for at least one week $(81.1 \%)$ were born at term (between 37 and 42 weeks). Among the singleton stillbirths, $37.1 \%$ were born at term, whereas this proportion fell to $27.4 \%$ among singletons who died in the first week after birth. This difference was so striking that no statistical test was needed to confirm it.

As in the case of singletons, the mean gestational age of twins who remained alive for at least one week after birth was significantly higher ( $36.7 \pm 3.4$ weeks) when compared with twins who died in the first week after birth 
Table V - Mean gestational age (MGA) in weeks and percentage of preterm ( $<37$ weeks), term (37-42 weeks) and post-mature ( $\geq 42$ weeks) newborns among singletons and twins.

\begin{tabular}{|lccccccc|}
\hline \multirow{2}{*}{$\begin{array}{l}\text { Gestation } \\
\text { (weeks) }\end{array}$} & \multicolumn{3}{c}{ Singletons } & & \multicolumn{3}{c}{ Twins } \\
\cline { 2 - 3 } \cline { 6 - 8 } & Stillbirths & $\begin{array}{c}\text { Neonatal } \\
\text { deaths }\end{array}$ & Alive & & Stillbirths & $\begin{array}{c}\text { Neonatal } \\
\text { deaths }\end{array}$ & Alive \\
\hline MGA & $34.4 \pm 5.6$ & $33.0 \pm 5.7$ & $39.5 \pm 2.4$ & & $35.6 \pm 5.1$ & $29.5 \pm 6.4$ & $36.7 \pm 3.4$ \\
$<37$ & 56.3 & 67.8 & 9.4 & & 46.7 & 82.3 & 44.9 \\
$37-42$ & 37.1 & 27.4 & 81.1 & & 53.3 & 17.7 & 53.1 \\
$\geq 42$ & 6.6 & 4.8 & 9.5 & & - & - & 2.0 \\
$\mathrm{~N}$ & 504 & 702 & 1119 & & 15 & 51 & 640 \\
\hline
\end{tabular}

Table VI - Mean birth weight (MBW) in grams according to sex $(M=$ males; $F=$ females $)$ and percentage of newborns with low $(<2500 \mathrm{~g})$ and very low $(<1500 \mathrm{~g})$ birth weight among singletons and twins.

\begin{tabular}{|c|c|c|c|c|c|c|}
\hline \multirow[t]{2}{*}{ Weight (g) } & \multicolumn{3}{|c|}{ Singletons } & \multicolumn{3}{|c|}{ Twins } \\
\hline & Stillbirths & Neonatal deaths & Alive & Stillbirths & Neonatal deaths & Alive \\
\hline MBW M & $\begin{array}{c}1823.9 \pm 979.5 \\
(N=414)\end{array}$ & $\begin{array}{l}1811.2 \pm 927.7 \\
\quad(\mathrm{~N}=515)\end{array}$ & $\begin{array}{c}3211.9 \pm 526.8 \\
(\mathrm{~N}=750)\end{array}$ & $\begin{array}{c}1881.6 \pm 618.3 \\
(\mathrm{~N}=19)\end{array}$ & $\begin{array}{c}1024.4 \pm 325.1 \\
(\mathrm{~N}=70)\end{array}$ & $\begin{array}{c}2331.0 \pm 615.5 \\
(\mathrm{~N}=711)\end{array}$ \\
\hline $\mathrm{F}$ & $\begin{array}{c}1792.8 \pm 957.8 \\
(\mathrm{~N}=333)\end{array}$ & $\begin{array}{c}1731.6 \pm 944.5 \\
(\mathrm{~N}=431)\end{array}$ & $\begin{array}{c}3127.4 \pm 477.2 \\
(\mathrm{~N}=765)\end{array}$ & $\begin{array}{c}1350.6 \pm 597.8 \\
(\mathrm{~N}=8)\end{array}$ & $\begin{array}{c}1128.6 \pm 535.9 \\
(N=44)\end{array}$ & $\begin{array}{c}2245.9 \pm 610.7 \\
(\mathrm{~N}=728)\end{array}$ \\
\hline$<2500 \mathrm{~g}$ & 72.4 & 76.6 & 7.9 & 88.9 & 98.2 & 61.1 \\
\hline$<1500 \mathrm{~g}$ & 43.9 & 48.9 & 0.9 & 33.3 & 86.8 & 9.9 \\
\hline
\end{tabular}

(29.5 \pm 6.4 weeks). The proportion of twins born at term among the former $(53.1 \%)$ was significantly greater $\left(\chi^{2}=\right.$ $23.784 ; 1$ d.f.; $\mathrm{P}<0.001)$ than that observed among early neonatal deaths $(17.7 \%)$. However, in contrast to singletons, the proportion of twins born at term was practically the same among the stillbirths (53.3\%) and newborns who remained alive for at least one week after birth $(53.1 \%)$.

Table VI shows that stillbirths had a higher mean birth weight than early neonatal deaths among both singletons and twins, although among the former the difference was not striking when the comparison took into account newborns with a low $\left(\chi^{2}=4.249 ; 1\right.$ d.f.; $\left.\mathrm{P}<0.05\right)$ or very low $\left(\chi^{2}=3.933 ; 1\right.$ d.f.; $\left.\mathrm{P}<0.05\right)$ birth weight. Among twins, this was only true for a low birth weight (Fisher's exact test: $\mathrm{P}=0.048$ ) since the proportion of newborns with a very low birth weight among twins who died in the first week after birth $(86.8 \%)$ was more than 2.5 times greater than among stillbirths $(33.3 \%)\left(\chi^{2}=50.025 ; 1\right.$ d.f.; $\mathrm{P}<$ $0.001)$. The mean birth weight of singletons who remained alive for at least seven days after birth was significantly higher than that of singleton stillbirths and early neonatal deaths. Among the former, the proportion of newborns with a low $(7.9 \%)$ and with very low $(0.9 \%)$ birth weight was so much smaller than among stillbirths (72.4 and 43.9\%) and early neonatal deaths (76.6 and 48.9\%) that statistical tests were not necessary to confirm these differences (Table VI)
The mean birth weight of twins who remained alive for at least one week after birth was significantly higher than those of stillbirths and early neonatal deaths. The proportion of newborns with a low birth weight among the twins who remained alive $(61.1 \%)$ was significantly lower than that among stillbirths $(88.9 \%)$ and early neonatal deaths $(98.2 \%)\left(\chi^{2}=8.662 ; 1\right.$ d.f.; $\mathrm{P}<0.01$ and $\chi^{2}=$ 63.170; 1 d.f.;P $<0.001$, respectively). These differences were even more striking when the proportion of newborns with a very low birth weight among the twins who remained alive $(9.9 \%)$ was compared with those observed among stillbirths (33.3\%) and early neonatal deaths (86.8\%).

The data in Tables V and VI thus point out clearly a close association between neonatal death rate and prematurity as well as low birth weight. The higher early neonatal death rate/stillbirth rate ratio of twins (2.9) compared to singletons (1.2) in Tables I and II was, undoubtedly, a consequence of the higher frequency of extreme prematurity and very low birth weight among twins.

As expected, the proportions of 1-min and 5-min Apgar scores under 7 among singletons and twins who remained alive for at least seven days after birth were strikingly smaller than among early neonatal deaths (Table VII). For this reason, statistical tests to demonstrate significance of such large differences were considered superfluous. As noted previously by Franchi-Pinto et al. (1999) in newborns who remained alive, singletons have a sig- 
Table VII - Mean 1-min and 5-min Apgar scores (MAS) and percentage of early neonatal deaths and newborns alive for at least seven days after birth (singletons and twins) who had 1-min and 5-min Apgar scores of $<7$ and $\geq 7$.

\begin{tabular}{|c|c|c|c|c|c|c|c|c|}
\hline \multirow{3}{*}{ Score } & \multicolumn{4}{|c|}{ One-minute Apgar score } & \multicolumn{4}{|c|}{ Five-minute Apgar score } \\
\hline & \multicolumn{2}{|c|}{ Neonatal deaths } & \multicolumn{2}{|c|}{ Alive } & \multicolumn{2}{|c|}{ Neonatal deaths } & \multicolumn{2}{|c|}{ Alive } \\
\hline & Singletons & Twins & Singletons & Twins & Singletons & Twins & Singletons & Twins \\
\hline MAS & $3.7 \pm 2.8$ & $3.5 \pm 2.4$ & $8.1 \pm 1.4$ & $7.4 \pm 2.2$ & $5.4 \pm 3.1$ & $6.0 \pm 2.4$ & $8.9 \pm 1.0$ & $8.9 \pm 1.8$ \\
\hline$<7$ & 78.3 & 85.9 & 9.2 & 23.6 & 55.9 & 50.5 & 3.4 & 9.5 \\
\hline$\geq 7$ & 21.7 & 14.1 & 90.8 & 76.4 & 44.1 & 49.5 & 96.6 & 90.5 \\
\hline $\mathrm{N}$ & 866 & 99 & 1522 & 1396 & 869 & 99 & 1519 & 1396 \\
\hline \multicolumn{3}{|c|}{$\chi^{2} ; 1$ d.f. $3.074 ; 0.05<\mathrm{P}<0.10$} & \multicolumn{2}{|c|}{$111.448 ; \mathrm{P}<0.001$} & \multicolumn{2}{|c|}{$1.057 ; 0.30<\mathrm{P}<0.50$} & \multicolumn{2}{|c|}{$45.600 ; \mathrm{P}<0.001$} \\
\hline
\end{tabular}

nificantly smaller proportion of Apgar scores under 7 (1 $\mathrm{min}$ and $5 \mathrm{~min}$ ) than twins. For newborns who died in the first week, there were no significant differences between singletons and twins in the proportion of newborns with Apgar scores under 7 (Table VII). This similarity, while suggesting that almost half $(44.6 \%)$ of the early neonatal deaths had 5-min Apgar scores varying from 7 to 10, also favors the hypothesis that Apgar scores $\geq 7$ obtained $5 \mathrm{~min}$ after birth cannot be considered as an adequate indicator of a good clinical condition of the newborn.

\section{ACKNOWLEDGMENTS}

Research supported by CNPq. Publication supported by FAPESP.

\section{RESUMO}

Dados a respeito de 116.699 partos (1062 gemelares e 115.637 únicos) ocorridos entre 1984 e 1996 na maior maternidade de Campinas, SP, Brasil, permitiram fazer as seguintes observações: 1) a despeito da baixa porcentagem de nascimentos gemelares $(0,9 \%)$, os gêmeos foram responsáveis por $10,7 \%$ dos óbitos neonatais precoces e 3,5\% dos natimortos. Em relação aos recém-nascidos de parto único, a probabilidade de natimortalidade e mortalidade neonatal precoce dos gêmeos foi, respectivamente, 1,9 e 6,5 vezes menor. 2) A proporção de gêmeos entre os óbitos neonatais precoces vem decrescendo, podendo essa tendência ser atribuída à melhoria da assistência pré- e perinatal. 3) Os três primeiros dias após o nascimento constituíram o período crítico de ocorrência dos óbitos neonatais tanto dos gêmeos quanto dos recém-nascidos de parto único. 4) A mortalidade perinatal incidiu mais frequientemente nos pares MM, que foram seguidos pelos pares FF, e foi menor nos pares MF. 5) A taxa anual de óbitos neonatais precoces tem decrescido nos recémnascidos de parto único e nos gêmeos, o mesmo ocorrendo com a taxa anual de natimortos de parto único, mas o decréscimo foi mais acentuado nos recém-nascidos do sexo feminino. 6) Durante o período analisado a razão de sexo esteve praticamente estável nos recém-nascidos de parto único vivos, mostrou variação cíclica nos recém-nascidos que foram a óbito na primeira semana e revelou tendência crescente nos natimortos. A razão de sexo dos gêmeos que foram a óbito na primeira semana e daqueles que sobreviveram também mostrou crescimento acentuado no período entre 1984 e 1996. 7) Nos recém-nascidos de parto único a idade gestacional média foi maior naqueles que sobreviveram, os quais foram seguidos pelos natimortos, sendo menor nos que foram a óbito na primeira semana. Nos gêmeos a idade gestacional média dos sobreviventes foi maior do que a dos falecidos na primeira semana, mas não diferiu daquela apresentada pelos natimortos. 8) O peso médio de todos os recémnascidos foi maior entre os sobreviventes, que foram seguidos pelos natimortos, e menor naqueles que foram a óbito na primeira semana. 9) Os índices de Apgar $\geq 7$ obtidos cinco minutos após o nascimento não podem ser considerados como um indicador de boas condições clínicas do recém-nascido, porque quase a metade dos óbitos neonatais precoces mostraram índices de Apgar de cinco minutos variando de 7 a 10.

\section{REFERENCES}

Alfieri, A., Gatti, I. and Alfieri, C. (1987). Weight and height growth in twins and children born in the last decade. Acta Genet. Med. Gemellol. 36: 209-211.

Apgar, V. (1953). A proposal for a new method of evaluation of the newborn infant. Anesth. Analg. 32: 260-267.

Barr, A. and Stevenson, A.C. (1961). Stillbirths and infant mortality in twins. Ann. Hum. Genet. 25: 131-140.

Beiguelman, B., Franchi-Pinto, C. and Magna, L.A. (1997). Biological and social traits associated with twinning among Caucasoids and Negroids. Braz. J. Genet. 20: 311-318.

Belitzky, R., Fescina, R.E. and Ucieda, F. (1978). Definiciones y terminologias aplicables al periodo perinatal. Recomendaciones de la Organización Mundial de la Salud y modificaciones de la F.I.G.O. Publicación Científica del CLAP 757: 136-147.

Bleker, O.P., Oosting, J. and Hemrika, D.J. (1988). On the cause of the retardation of fetal growth in multiple gestations. Acta Genet. Med. Gemellol. 37: 41-46.

Bonnelykke, B., Sogaard, J. and Nielsen, J. (1987). Seasonality in twin birth rates, Denmark, 1936-1984. J. Epidemiol. Community Health 41: 338-343.

Buckler, J.M.H. and Buckler, J.B. (1987). Growth characteristics in twins and higher order multiple births. Acta Genet. Med. Gemellol. 36: 197208

Chen, C.J., Wang, C.J., Yu, M.W. and Lee, T.K. (1992). Perinatal mortality and prevalence of major congenital malformations of twins in Taipei City. Acta Genet. Med. Gemellol. 41: 197-203.

Committee on Fetus and Newborn, American Academy of Pediatrics (1986). Use and abuse of the Apgar scores. Pediatrics 78: 1148-1149.

Doherty, J.D.H. (1988). Perinatal mortality in twins, Australia, 1973-1980: II maternal age, lethal congenital malformations and sex. Acta Genet. 
Med. Gemellol. 37: 321-329.

Fanaroff, A.A. and Martin, R.J. (1992). Neonatal-Perinatal Medicine: Diseases of the Fetus and Infant. Vol. 2, 5th ed. Mosby-Yearbook, New York.

Franchi-Pinto, C., Dal Colletto, G.M.D., Krieger, H. and Beiguelman, B. (1999). Genetic effect on Apgar score. Genet. Mol. Biol. 22: 13-16.

Fraser, D., Picard, R. and Picard, E. (1991). Factors associated with neonatal problems in twin gestations. Acta Genet. Med. Gemellol. 40 : 193-200.

Gedda, L., Brenci, G. and Gatti, I. (1981). Low birth weight in twins versus singletons: separate entities and different implications for child growth and survival. Acta Genet. Med. Gemellol. 30: 1-8.

Grothe, W. and Rüttgers, H. (1985). Twin pregnancies: an 11-year review. Acta Genet. Med. Gemellol. 34: 49-58.

Keith, L. (1994). Mortality and morbidity among twins: recent observations from the United States. Acta Genet. Med. Gemellol. 43: 25-31.

Kiely, J.L. (1991). Time trends in neonatal mortality among twins and singletons in New York City, 1968-1986. Acta Genet. Med. Gemellol. 40: 303-309.

Leroy, B., Lefort, F., Neveu, P., Risse, R.J., Trévise, P. and Jeny, R. (1982) Intrauterine growth charts for twin fetuses. Acta Genet. Med. Gemellol. 31: 199-206.

Lowe, C.R. and Record, R.G. (1951). Risk of stillbirth in twin pregnancy related to sex and maternal age. Br. J. Soc. Med. 5: 34-40.

Luke, B. (1996). Reducing fetal deaths in multiple births: optimal birth weight and gestational ages for infants of twin and multiple births. Acta Genet. Med. Gemellol. 45: 333-348.

Lumme, R.H. and Saarikoski, S.V. (1988). Perinatal deaths in twins preg- nancy: a 22 years review. Acta Genet. Med. Gemellol. 37: 47-54

McKeown, T. and Record, R.G. (1952). Observations on foetal growth in multiple pregnancy in man. J. Endocrinol. 5: 387-401.

Myrianthopoulos, N.C. (1970). An epidemiologic survey of twins in a large, prospectively studied population. Am. J. Hum. Genet. 22: 611-629.

Osbourne, G.K. and Patel, N.B. (1985). An assessment of perinatal mortality in twin pregnancies in Dundee. Acta Genet. Med. Gemellol. 34: 193-199.

Papiernik, E., Mussy, M.A., Vial, M. and Richard, A. (1985). A low rate of perinatal deaths for twin births. Acta Genet. Med. Gemellol. 34: 201-206.

Pilotto, R.F., Magna, L.A. and Beiguelman, B. (1993). Factors influencing human birth weight in normal pregnancy: a prospective study in a Brazilian university hospital. Rev. Bras. Genet. 16: 457-469.

Powers, W.F. (1973). Twin pregnancy, complications and treatment. Obstet. Gynecol. 42: 795-808

Rydhström, H. (1990). The effects of maternal age, parity and sex of the twins on twin perinatal mortality. A population based study. Acto Genet. Med. Gemellol. 39: 401-408.

Spellacy, W.N., Handler, A. and Ferre, C.D. (1990). A case-control study of 1253 twin pregnancies from 1982-1987 perinatal data base. Obstet. Gynecol. 75: 168-171.

Watson, P. and Campbell, D.M. (1986). Preterm deliveries in twin pregnancies in Oxford. Acta Genet. Med. Gemellol. 35: 193-199.

Weinberg, W. (1901). Beiträge zur Physiologie und Pathologie der Mehrlingsgeburten beim Menschen. Pflügers Arch. Ges. Physiol. 88: 346-430.

(Received February 3, 1999) 
